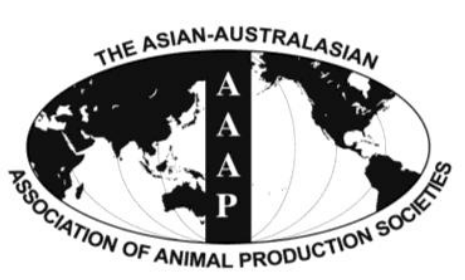

Asian Australas. J. Anim. Sci.

Vol. 28, No. 1 : 102-110 January 2015

http://dx.doi.org/10.5713/ajas.14.0161

\title{
Effect of Different Inclusion Level of Condensed Distillers Solubles Ratios and Oil Content on Amino Acid Digestibility of Corn Distillers Dried Grains with Solubles in Growing Pigs
}

\author{
P. Li, X. Xu, Q. Zhang, J. D. Liu, Q. Y. Li, S. Zhang, X. K. Ma, and X. S. Piao* \\ State Key Laboratory of Animal Nutrition, Ministry of Agriculture Feed Industry Centre, \\ China Agricultural University, Beijing 100193, China
}

\begin{abstract}
The purpose of this experiment was to determine and compare the digestibility of crude protein (CP) and amino acids (AA) in full-oil (no oil extracted) and de-oiled (oil extracted) corn distillers dried grains with solubles (DDGS) with different condensed distillers solubles (CDS) ratios. Six barrows $(29.6 \pm 2.3 \mathrm{~kg}$ ) fitted with ileal T-cannula were allotted into a $6 \times 6$ Latin square design. Each period was comprised of a 5-d adaption period followed by a 2-d collection of ileal digesta. The five test diets contained $62 \%$ DDGS as the sole source of AA. A nitrogen-free diet was used to measure the basal endogenous losses of CP and AA. Chromic oxide (0.3\%) was used as an index in each diet. The results showed that $\mathrm{CP}$ and AA were very similar in 5 DDGS, but the standardized ileal digestibility (SID) of lysine (from $56.16 \%$ to $71.15 \%$ ) and tryptophan (from $54.90 \%$ to $68.38 \%$ ) had the lowest values and largest variation within the essential AA, which suggests reduced availability of AA and different levels of Maillard reactions in the five DDGS. The apparent ileal digestibility and SID of CP and most of AA in full-oil DDGS (sources 1 and 2) were greater $(\mathrm{p}<0.05)$ than de-oiled DDGS (sources 3,4 , and 5). Comparing the AA SID in the 5 DDGS, full-oil with low CDS ratio DDGS (source 1) had non-significantly higher values (p $>0.05$ ) than full-oil with high CDS ratio DDGS (source 2); however, the SID of most AA of de-oiled with low CDS ratios DDGS (source 3) were non-significantly lower ( $p>0.05$ ) than de-oiled with high CDS ratio DDGS (source 4); and the de-oiled DDGS with middle CDS ratio (source 5) but with different drying processing had the lowest SID AA values. In conclusion, de-oiled DDGS had lower SID of CP and AA than full-oil DDGS; a higher CDS ratio tended to decrease the SID of AA in full-oil DDGS but not in de-oiled DDGS; and compared with CDS ratio, processing, especially drying, may have more of an effect on AA digestibility of DDGS. (Key Words: Amino Acid Digestibility, Condensed Distillers Solubles Ratio, Corn Distillers Dried Grains with Solubles, Full-oil and De-oiled, Growing Pigs, Processing)
\end{abstract}

\section{INTRODUCTION}

Corn distillers dried grains with solubles (DDGS) is a rich source of protein and amino acids (AA) for pig feed (Stein and Shurson, 2009b). However, the high variation in DDGS AA composition and relatively low AA digestibility may play a role in its limited use in swine diets (Fastinger and Mahan, 2006; Liu, 2011).

The ratio of wet distillers grains (WDG) and condensed distillers solubles (CDS) was considered to be one of most

\footnotetext{
* Corresponding Author: X. S. Piao. Tel: +86-10-62733588, Fax: +86-10-62733688, E-mail: piaoxsh@mafic.ac.cn Submitted Mar. 3, 2014; Revised Apr. 22, 2014; Accepted Jul. 20, 2014
}

important factors to affect the color, chemical composition and AA digestibility of corn DDGS for pigs (MartinezAmezcua et al., 2007; Kingsly et al., 2010).

Traditional full-oil corn DDGS (no oil extracted) contain approximately 10\% oil (Stein and Shurson, 2009b). Over the past several years, the extraction of oil from corn has led to the existence of de-oiled (oil extracted) corn DDGS by-products. When most of the oil is removed, crude protein $(\mathrm{CP}), \mathrm{AA}$, fiber and mineral concentrations increase proportionately in the remaining coproduct (Jacela et al., 2011). In contrast to full-oil DDGS, very little research has been conducted to determine the apparent ileal digestibility (AID) and the standardized ileal digestibility (SID) of CP and AA in de-oiled DDGS when fed to pigs (Jacela et al., 
2011; Ren et al., 2011). Furthermore, there have been no reports of AA digestibility in de-oiled corn DDGS with different CDS ratios.

Therefore, the objectives of the present experiment were to determine the AID and SID of AA and CP in de-oiled and full-oil DDGS with different CDS ratios when fed to growing pigs and to compare the difference of these values by their processing and chemical composition.

\section{MATERIALS AND METHODS}

\section{General}

The China Agricultural University Laboratory Animal Welfare and Animal Experimental Ethical Inspection Committee (Beijing, China) reviewed and approved the protocols used in the study. Two of full-oil corn DDGS and three of de-oiled corn DDGS samples were collected at the same time from a beverage plant and a fuel ethanol plant, respectively. The DDGS (source 5) was dried by tube bundle dryer and cage mill flash dryer (about 1/2, respectively), while the DDGS (sources 3 and 4) were only dried by tube bundle dryer. The information and chemical composition of the samples are shown in Table 1 and 2 , respectively.

\section{Animals and experimental design}

The experiment was conducted in the Metabolism Laboratory of Ministry of Agriculture Feed Industry Centre (China Agricultural University, Beijing, China), and was designed to measure the AID and SID values for CP and AA in the five sources of corn DDGS. Eight crossbred (Duroc $x$ LandracexYorkshire) barrows (initial body weight [BW] = $29.6 \pm 2.3 \mathrm{~kg}$ ) were fitted with a simple T-cannula near the distal ileum according to the procedures described by Stein et al. (1998). After surgery, pigs were housed individually in stainless steel metabolism cages $(1.4 \times 0.7 \times 0.6 \mathrm{~m})$ in an environmentally controlled room $\left(20 \pm 2^{\circ} \mathrm{C}\right)$. Pigs were allowed a 2 week recovery before the experiment was

Table 1. Sources of corn distillers dried grains with solubles used in the experiment

\begin{tabular}{lcllc}
\hline No. & Product $^{1}$ & Kind of plant & Oil condition & $\begin{array}{c}\text { CDS/DDGS } \\
(\%, \text { DM basis })\end{array}$ \\
\hline 1 & A1 & Beverage & Full-oil & 26 \\
2 & A2 & Beverage & Full-oil & 30 \\
3 & B1 & Fuel & De-oiled & 25 \\
4 & B2 & Fuel & De-oiled & 33 \\
$5^{2}$ & B3 & Fuel & De-oiled & 30 \\
\hline
\end{tabular}

CDS, condensed distillers solubles; DDGS, distillers dried grains with solubles; DM, dry matter.

${ }^{1}$ The same capital letter means from the same plant, and the different numbers mean different products or different batches or treatments from these plants.

${ }^{2}$ Dried by tube bundle dryer and cage mill flash dryer (about $1 / 2$, respectively), the other DDGS were dried by tube bundle dryer. initiated. During the recovery period, a nutrient balanced grower diet $(18 \% \mathrm{CP})$ was provided. After the recuperation period, six healthy pigs with similar physiological status were chosen and allotted to a $6 \times 6$ Latin square design with 6 periods and 6 diets.

Six diets were prepared before the initiation of the experiment (Tables 3 and 4). In five DDGS diets, DDGS was the sole source of $\mathrm{CP}$ and AA. A N-free diet was used to estimate basal endogenous losses of $\mathrm{CP}$ and AA. Chromic oxide $(0.3 \%)$ was included in the six diets as an indigestible index.

Sucrose was included at $10 \%$ in the DDGS diets and at $15 \%$ in the $\mathrm{N}$-free diets to increase palatability. Soybean oil was added to increase energy density and reduce dust. Acetate cellulose (Chemical Reagents Company, Beijing, China), a synthetic fiber, was included in the $\mathrm{N}$-free diet (4\%) to mimic the concentration of crude fiber in the DDGS diets. As potassium and magnesium were lacking in the $\mathrm{N}$ free diets, these minerals were provided in the form of potassium carbonate and magnesium oxide, respectively. Vitamins and minerals were supplemented in all diets to meet or exceed the estimated nutrient requirements for growing pigs recommended by NRC (1998).

The daily feed allowance was equivalent to $4 \%$ of BW at the beginning of each experimental period and was divided into two equal amounts at 0830 and $1630 \mathrm{~h}$ and fed in mash form. The pigs had unlimited access to water through low-pressure drinking nipples. Each experimental period lasted 7 days. The initial 5 days of each period were considered as an adaptation period to the diets, and the remaining 2 days were used for ileal digesta collection in 9 $\mathrm{h}$ periods as described by Stein et al. (2006). A $200 \mathrm{~mL}$ plastic bag was attached to the ileal cannula barrel using a cable tie, and digesta flowing into the bag were collected. During the collection period, bags were removed whenever they were filled with digesta, and immediately stored at $-20^{\circ} \mathrm{C}$ to prevent bacterial degradation of AA in the digesta.

At the end of the experiment, the ileal samples were thawed, mixed within animal and diet, and a subsample was taken and lyophilised in a vacuum-freeze dryer (Tofflon Freezing Drying Systems, Minhang District, Shanghai, China), ground through a $1 \mathrm{~mm}$ screen, and thoroughly mixed before a subsample was collected for chemical analysis.

\section{Chemical analysis}

All chemical analyses were conducted in duplicate and repeated if the results differed by more than 5\%. Dry matter (DM), ether extract (EE), CP $(\mathrm{N} \times 6.25)$, ash, calcium $(\mathrm{Ca})$ and phosphorus $(\mathrm{P})$ content of the diets and corn DDGS were analyzed according to the procedures of the Association of Official Analytical Chemists (AOAC, 2007). Crude fiber, neutral detergent fiber (NDF) and acid 
Table 2. Analyzed composition (as fed basis) and color of corn distillers dried grains with solubles

\begin{tabular}{|c|c|c|c|c|c|}
\hline \multirow{2}{*}{ Items } & \multicolumn{2}{|c|}{ Full-oil DDGS $^{1}$} & \multicolumn{3}{|c|}{ De-oiled DDGS $^{1}$} \\
\hline & 1 & 2 & 3 & 4 & 5 \\
\hline \multicolumn{6}{|l|}{ Ingredient } \\
\hline DM (\%) & 89.96 & 88.80 & 87.89 & 87.67 & 88.69 \\
\hline $\mathrm{GE}(\mathrm{kcal} / \mathrm{kg})$ & 4,589 & 4,600 & 4,256 & 4,229 & 4,306 \\
\hline $\mathrm{CP}(\%)$ & 28.80 & 27.30 & 28.40 & 28.97 & 30.86 \\
\hline Lys:CP ratio ${ }^{2}$ & 2.87 & 2.96 & 2.88 & 2.87 & 2.90 \\
\hline $\mathrm{EE}(\%)$ & 8.66 & 10.40 & 3.22 & 3.06 & 2.50 \\
\hline $\mathrm{ST}(\%)$ & 13.72 & 13.27 & 11.29 & 12.62 & 11.06 \\
\hline $\mathrm{CF}(\%)$ & 5.88 & 5.01 & 6.72 & 5.98 & 6.54 \\
\hline $\operatorname{NDF}(\%)$ & 31.42 & 28.72 & 38.57 & 35.09 & 36.09 \\
\hline $\operatorname{ADF}(\%)$ & 9.71 & 8.19 & 12.29 & 9.20 & 10.30 \\
\hline $\mathrm{HC}^{3}(\%)$ & 21.73 & 20.53 & 26.29 & 25.89 & 25.79 \\
\hline $\mathrm{Ca}(\%)$ & 0.08 & 0.12 & 0.04 & 0.04 & 0.03 \\
\hline $\mathrm{P}(\%)$ & 0.55 & 0.71 & 0.53 & 0.81 & 0.85 \\
\hline $\operatorname{Ash}(\%)$ & 4.33 & 4.94 & 4.59 & 4.79 & 4.65 \\
\hline \multicolumn{6}{|l|}{ Essential AA (\%) } \\
\hline Arginine & 1.03 & 1.04 & 0.98 & 1.02 & 1.06 \\
\hline Histidine & 0.79 & 0.75 & 0.75 & 0.75 & 0.79 \\
\hline Isoleucine & 0.97 & 0.92 & 1.02 & 1.02 & 1.07 \\
\hline Leucine & 3.59 & 3.29 & 3.69 & 3.61 & 3.69 \\
\hline Lysine & 0.83 & 0.81 & 0.82 & 0.83 & 0.90 \\
\hline Methionine & 0.45 & 0.44 & 0.52 & 0.52 & 0.47 \\
\hline Phenylalanine & 1.41 & 1.32 & 1.45 & 1.46 & 1.53 \\
\hline Threonine & 1.11 & 1.07 & 1.05 & 1.05 & 1.14 \\
\hline Tryptophan & 0.16 & 0.17 & 0.17 & 0.18 & 0.20 \\
\hline Valine & 1.46 & 1.38 & 1.35 & 1.35 & 1.45 \\
\hline \multicolumn{6}{|c|}{ Nonessential AA (\%) } \\
\hline Alanine & 2.17 & 2.00 & 2.14 & 2.13 & 2.26 \\
\hline Asparagine & 1.89 & 1.88 & 1.82 & 1.85 & 2.00 \\
\hline Cysteine & 0.40 & 0.39 & 0.41 & 0.41 & 0.39 \\
\hline Glutamine & 3.04 & 2.69 & 2.52 & 2.55 & 2.57 \\
\hline Glycine & 1.08 & 1.06 & 0.98 & 1.03 & 1.13 \\
\hline Proline & 2.51 & 2.26 & 2.42 & 2.38 & 2.39 \\
\hline Serine & 3.81 & 3.46 & 3.73 & 3.72 & 3.88 \\
\hline Tyrosine & 0.86 & 0.84 & 0.88 & 0.88 & 0.88 \\
\hline Total AA (\%) & 28.41 & 26.60 & 27.61 & 27.64 & 28.67 \\
\hline \multicolumn{6}{|l|}{ Color $^{4}$} \\
\hline $\mathrm{L}^{*}$ & $47.89^{b}$ & $45.61^{\mathrm{c}}$ & $51.04^{\mathrm{a}}$ & $47.56^{\mathrm{b}}$ & $45.44^{\mathrm{c}}$ \\
\hline$a^{*}$ & $8.66^{\mathrm{c}}$ & $9.41^{\mathrm{b}}$ & $8.80^{\mathrm{c}}$ & $9.88^{\mathrm{b}}$ & $11.10^{\mathrm{a}}$ \\
\hline $\mathrm{b}^{*}$ & 35.33 & 34.78 & 35.47 & 34.85 & 35.53 \\
\hline
\end{tabular}

DDGS, distillers dried grains with solubles; DM, dry matter; GE, gross energy; CP, crude protein; EE, ether extract; ST, starch; CF, crude fiber; NDF, neutral detergent fiber; ADF, acid detergent fiber; HC, hemicellulose; AA, amino acids.

${ }^{1}$ Sources of corn distillers dried grains with solubles are described in Table 1.

${ }^{2}$ Calculated by expressing the concentration of Lysine in each ingredient as a percentage of the concentration of $\mathrm{CP}$.

${ }^{3} \mathrm{HC}=\mathrm{NDF}-\mathrm{ADF}$.

${ }^{4}$ Mean of 10 observations. L*, lightness of sample; 0, black; 100, white; greater values of $\mathrm{a}^{*}$ and $\mathrm{b}^{*}$ indicate greater degree of redness and yellowness, respectively.

${ }^{a, b, c}$ Means in the same row with different superscripts are significantly different $(\mathrm{p}<0.01)$.

detergent fiber (ADF) were determined using fiber bags (Model F57, Ankom Technology, Macedon, NY, USA) and a Ankom A200 fiber analyzer (Ankom Technology, USA) after an adaptation procedure as described by Van Soest et al. (1991). The concentration of NDF was analyzed using heat stable $\alpha$-amylase and sodium sulphite without correction for insoluble ash. The gross energy (GE) of corn DDGS samples were measured using an Automatic Isoperibol Oxygen Bomb Calorimeter (Parr 1281 Calorimeter, Moline, IL, USA). Total starch was obtained 
Table 3. Ingredient composition of the experimental diets, as-fed basis

\begin{tabular}{|c|c|c|}
\hline Ingredient (\%) & DDGS diet & $\mathrm{N}$-free diet \\
\hline Distillers dried grains with solubles & 62.00 & - \\
\hline Cornstarch & 23.00 & 73.35 \\
\hline Sucrose & 10.00 & 15.00 \\
\hline Soybean oil & 2.00 & 3.00 \\
\hline Cellulose acetate $^{1}$ & - & 4.00 \\
\hline Limestone & 0.70 & - \\
\hline Dicalcium phosphate & 1.20 & 3.00 \\
\hline Salt & 0.30 & 0.45 \\
\hline Chromic oxide & 0.30 & 0.30 \\
\hline Potassium carbonate & - & 0.30 \\
\hline Magnesium oxide & - & 0.10 \\
\hline Vitamin and trace element premix ${ }^{2}$ & 0.50 & 0.50 \\
\hline \multicolumn{3}{|c|}{$\begin{array}{l}\text { DDGS, distillers dried grains with solubles. } \\
{ }^{1} \text { Made by Chemical Reagents Company, Beinging, China. } \\
{ }^{2} \text { Provided the following quantities of vitamins and minerals per kg of } \\
\text { complete diet: } \mathrm{Mn}, 50 \mathrm{mg}(\mathrm{MnO}) ; \mathrm{Fe}, 125 \mathrm{mg}\left(\mathrm{FeSO}_{4} \cdot \mathrm{H}_{2} \mathrm{O}\right) ; \mathrm{Zn}, 125 \mathrm{mg} \\
(\mathrm{ZnO}) ; \mathrm{Cu}, 150 \mathrm{mg}\left(\mathrm{CuSO}_{4} \cdot 5 \mathrm{H}_{2} \mathrm{O}\right) ; \mathrm{I}, 50 \mathrm{mg}\left(\mathrm{CaI}_{2}\right) ; \mathrm{Se}, 0.30 \mathrm{mg} \\
\left(\mathrm{Na}_{2} \mathrm{SeO}_{3}\right) \text {, retinyl acetate, } 4,500 \mathrm{IU} \text {; cholecalciferol, } 1,350 \mathrm{IU} \text {; DL- } \alpha \text { - } \\
\text { tocopheryl acetate, } 13.5 \mathrm{mg} \text {; menadione sodium bisulfite complex, } 2.7 \\
\mathrm{mg} \text {; niacin, } 18 \mathrm{mg} \text {; vitamin } \mathrm{B}_{12}, 27.6 \mu \mathrm{g} \text {; thiamine, } 0.6 \mathrm{mg} \text {; pyridoxine, } \\
0.9 \mathrm{mg} \text {; riboflavin, } 1.8 \mathrm{mg} \text {; D-calcium-pantothenate, } 10.8 \mathrm{mg} \text {; nicotinic } \\
\text { acid, } 30.3 \mathrm{mg} \text {; choline chloride, } 210 \mathrm{mg} \text {. }\end{array}$} \\
\hline
\end{tabular}

using the glucoamylase procedure (AOAC, 2007). Color scores $\left(\mathrm{L}^{*}, \mathrm{a}^{*}\right.$ and $\left.\mathrm{b}^{*}\right)$ of all DDGS samples were obtained using Minolta Chroma Meter CR-400 (Minolta, Osaka, Japan). The mean color score was the average of 10 measurements. Low values for $\mathrm{L}^{*}$ indicate a dark color, whereas high scores indicate a light color $(0=$ black; $100=$ white). Greater values of $a^{*}$ and $b^{*}$ indicate a greater degree of redness and yellowness, respectively.

Amino acids in corn DDGS, diets and digesta were hydrolyzed with $6 \mathrm{~N} \mathrm{HCl}$ at $110^{\circ} \mathrm{C}$ for $24 \mathrm{~h}$ and analyzed for 15 AA using an Amino Acid Analyzer (Hitachi L-8900, Tokyo, Japan). Methionine and cysteine were determined as methionine sulfone and cysteic acid after cold performic acid oxidation overnight and hydrolyzing with $7.5 \mathrm{~N} \mathrm{HCl}$ at $110^{\circ} \mathrm{C}$ for $24 \mathrm{~h}$ using an Amino Acid Analyzer (Hitachi L8800, Tokyo, Japan). Tryptophan was determined after $\mathrm{LiOH}$ hydrolysis for $22 \mathrm{~h}$ at $110^{\circ} \mathrm{C}$ using HPLC (Agilent 1200 Series, Santa Clara, CA, USA). The chromium content in the diets and digesta was measured using an Atomic Absorption Spectrophotometer (Hitachi Z-5000 Automatic Absorption Spectrophotometer, Tokyo, Japan) according to the procedure of Williams et al. (1962).

\section{Calculations}

Apparent ileal digestibility values for AA were calculated as described by Stein et al. (2007):

$$
\operatorname{AID}(\%)=\left[1-\left(\mathrm{AA}_{\text {digesta }} / \mathrm{AA}_{\text {diet }}\right) \times\left(\mathrm{Cr}_{\text {diet }} / \mathrm{Cr}_{\text {digesta }}\right)\right] \times 100
$$

Table 4. Analyzed concentration of DM and nutrients in experimental diets (\%, as-fed basis)

\begin{tabular}{|c|c|c|c|c|c|c|}
\hline \multirow{2}{*}{ Items } & \multicolumn{2}{|c|}{ Full-oil DDGS $^{1}$} & \multicolumn{3}{|c|}{ De-oiled DDGS ${ }^{1}$} & \multirow{2}{*}{ N-free } \\
\hline & 1 & 2 & 3 & 4 & 5 & \\
\hline $\mathrm{DM}$ & 93.43 & 92.94 & 93.18 & 92.76 & 93.09 & 91.64 \\
\hline $\mathrm{CP}$ & 18.81 & 17.30 & 17.81 & 19.23 & 19.71 & 0.34 \\
\hline \multicolumn{7}{|l|}{ Essential AA } \\
\hline Arginine & 0.72 & 0.70 & 0.66 & 0.72 & 0.75 & - \\
\hline Histidine & 0.53 & 0.49 & 0.49 & 0.50 & 0.51 & - \\
\hline Isoleucine & 0.65 & 0.62 & 0.68 & 0.69 & 0.73 & - \\
\hline Leucine & 2.37 & 2.16 & 2.51 & 2.42 & 2.55 & - \\
\hline Lysine & 0.52 & 0.50 & 0.50 & 0.54 & 0.55 & - \\
\hline Methionine & 0.35 & 0.34 & 0.36 & 0.35 & 0.34 & - \\
\hline Phenylalanine & 0.96 & 0.90 & 1.00 & 1.01 & 1.05 & - \\
\hline Threonine & 0.72 & 0.69 & 0.70 & 0.73 & 0.77 & - \\
\hline Tryptophan & 0.13 & 0.13 & 0.13 & 0.13 & 0.15 & - \\
\hline Valine & 0.95 & 0.92 & 0.93 & 0.98 & 1.03 & - \\
\hline \multicolumn{7}{|l|}{ Nonessential AA } \\
\hline Alanine & 1.41 & 1.30 & 1.41 & 1.44 & 1.52 & - \\
\hline Asparagine & 1.18 & 1.10 & 1.21 & 1.29 & 1.37 & - \\
\hline Cysteine & 0.42 & 0.41 & 0.42 & 0.41 & 0.39 & - \\
\hline Glutamine & 2.12 & 1.85 & 2.00 & 2.01 & 2.01 & - \\
\hline Glycine & 0.72 & 0.69 & 0.66 & 0.74 & 0.78 & - \\
\hline Proline & 1.71 & 1.48 & 1.58 & 1.54 & 1.59 & - \\
\hline Serine & 2.54 & 2.29 & 2.53 & 2.53 & 2.65 & - \\
\hline Tyrosine & 0.60 & 0.57 & 0.64 & 0.61 & 0.64 & - \\
\hline
\end{tabular}

DDGS, distillers dried grains with solubles; DM, dry matter; $\mathrm{CP}$, crude protein; AA, amino acids.

${ }^{1}$ Sources of corn DDGS are described in Table 1. 
where $\mathrm{AA}_{\text {digesta }}$ is the $\mathrm{AA}$ concentration in the ileal digesta $\mathrm{DM}(\mathrm{g} / \mathrm{kg}), \mathrm{AA}_{\text {diet }}$ is the $\mathrm{AA}$ concentration in the diet $\mathrm{DM}(\mathrm{g} / \mathrm{kg}), \mathrm{Cr}_{\text {diet }}$ is the chromium concentration in the diet DM $(\mathrm{g} / \mathrm{kg})$, and $\mathrm{Cr}_{\text {digesta }}$ is the chromium concentration in the ileal digesta DM $(\mathrm{g} / \mathrm{kg})$.

The endogenous loss $/ \mathrm{kg}$ of dry matter intake (DMI, $\mathrm{IAA}_{\text {end }}$ ) of each AA was determined from pigs fed the Nfree diet based on the following equation:

$$
\mathrm{IAA}_{\text {end }}=\left[\mathrm{AA}_{\text {digesta }} \times\left(\mathrm{Cr}_{\text {diet }} / \mathrm{Cr}_{\text {digesta }}\right)\right]
$$

where $\mathrm{IAA}_{\text {end }}$ is the basal endogenous loss of an AA $\left(\mathrm{g} / \mathrm{kg}\right.$ of DMI), $\mathrm{AA}_{\text {digesta }}$ is the concentration of that $\mathrm{AA}$ in the digesta, and $\mathrm{Cr}_{\text {diet }}$ and $\mathrm{Cr}_{\text {digesta }}$ are the chromium concentration in diet and digesta, respectively $(\mathrm{g} / \mathrm{kg}$ of $\mathrm{DM})$. The average $\mathrm{IAA}_{\text {end }}$ for the 6 pigs was used to calculate the SID of AA in all diets.

The SID was calculated by the following equation:

$$
\operatorname{SID}(\%)=\mathrm{AID}+\left[\left(\mathrm{IAA}_{\text {end }} / \mathrm{AA}_{\text {diet }}\right) \times 100\right]
$$

\section{Statistical analysis}

Data were analyzed using PROC GLM (SAS Inst. Inc., Cary, NC, USA). Each pig was the experimental unit. Pig and period were considered random effects. The
CONTRAST statement of SAS was used to compare the values from the full-oil DDGS source with the de-oiled DDGS source. Results were expressed as standard error of the mean. In all analyses, the differences were considered significant if $\mathrm{p}<0.05$.

\section{RESULTS}

\section{Chemical characteristics of distillers dried grains with solubles}

The DM contents in the 5 DDGS were similar (Table 2).

The 5 DDGS (as-fed basis) ranged from 4,229 to 4,600 $\mathrm{kcal} / \mathrm{kg}$ of GE, $27.30 \%$ to $30.86 \% \mathrm{CP}, 2.50 \%$ to $10.40 \%$ fat, $28.72 \%$ to $38.57 \% \mathrm{NDF}, 8.19 \%$ to $12.29 \% \mathrm{ADF}, 0.53 \%$ to $0.85 \% \mathrm{P}$ and $4.33 \%$ to $4.94 \%$ ash. Lysine concentrations (as-fed basis) of the DDGS ranged from $0.81 \%$ to $0.90 \%$. The Lys:CP ratio of all DDGS was more than 2.80 .

\section{Ileal amino acid digestibility}

The AID and SID of CP and AA in the 5 corn DDGS are summarized in Table 5 and 6, respectively. The AID for CP was $71.96 \%$ in DDGS source 1 (Table 5), this value was higher $(\mathrm{p}<0.05)$ than the values obtained for sources 3 and 5 (63.50\% and $62.12 \%$, respectively) but no different from sources 2 and 4 (67.76\% and 66.34\%, respectively). There

\begin{tabular}{|c|c|c|c|c|c|c|c|c|}
\hline \multirow{2}{*}{ Items } & \multicolumn{2}{|c|}{ Full-oil DDGS } & \multicolumn{3}{|c|}{ De-oiled DDGS } & \multirow{2}{*}{ SEM } & \multicolumn{2}{|r|}{ p-value } \\
\hline & 1 & 2 & 3 & 4 & 5 & & DDGS $^{3}$ & Full-oil vs de-oiled $^{4}$ \\
\hline $\mathrm{CP}$ & $71.96^{\mathrm{a}}$ & $67.76^{\mathrm{ab}}$ & $63.50^{\mathrm{b}}$ & $66.34^{\mathrm{ab}}$ & $62.12^{\mathrm{b}}$ & 2.24 & $<0.05$ & $<0.01$ \\
\hline \multicolumn{9}{|l|}{ Essential AA } \\
\hline Arginine & 81.59 & 80.17 & 76.64 & 77.22 & 75.88 & 1.78 & 0.09 & $<0.01$ \\
\hline Histidine & $78.51^{\mathrm{a}}$ & $75.21^{\mathrm{ab}}$ & $70.98^{\mathrm{bc}}$ & $70.07^{\mathrm{bc}}$ & $66.78^{\mathrm{c}}$ & 2.10 & $<0.01$ & $<0.01$ \\
\hline Isoleucine & $79.93^{\mathrm{a}}$ & $77.23^{\mathrm{ab}}$ & $74.98^{\mathrm{ab}}$ & $76.20^{\mathrm{ab}}$ & $71.07^{\mathrm{b}}$ & 2.08 & $<0.05$ & $<0.05$ \\
\hline Leucine & $88.46^{\mathrm{a}}$ & $87.13^{\mathrm{a}}$ & $81.41^{\mathrm{b}}$ & $85.01^{\mathrm{ab}}$ & $80.86^{\mathrm{b}}$ & 1.47 & $<0.01$ & $<0.01$ \\
\hline Lysine & $65.69^{\mathrm{a}}$ & $58.86^{\mathrm{ab}}$ & $58.80^{\mathrm{ab}}$ & $58.19^{\mathrm{ab}}$ & $50.92^{\mathrm{b}}$ & 3.47 & $<0.05$ & $<0.05$ \\
\hline Methionine & $85.02^{\mathrm{a}}$ & $83.26^{\mathrm{a}}$ & $83.92^{\mathrm{a}}$ & $81.54^{\mathrm{ab}}$ & $77.87^{\mathrm{b}}$ & 1.45 & $<0.05$ & $<0.05$ \\
\hline Phenylalanine & 84.95 & 83.70 & 81.08 & 82.04 & 79.98 & 1.63 & 0.17 & $<0.05$ \\
\hline Threonine & 67.68 & 62.71 & 60.88 & 62.65 & 58.10 & 3.02 & 0.21 & 0.08 \\
\hline Tryptophan & 60.85 & 55.77 & 56.14 & 52.95 & 48.23 & 4.68 & 0.20 & $<0.05$ \\
\hline Valine & 77.29 & 74.27 & 70.34 & 73.59 & 68.05 & 2.38 & 0.06 & $<0.05$ \\
\hline \multicolumn{9}{|l|}{ Nonessential AA } \\
\hline Alanine & $80.96^{\mathrm{a}}$ & $78.39^{\mathrm{ab}}$ & $73.22^{\mathrm{b}}$ & $74.97^{\mathrm{b}}$ & $72.21^{\mathrm{b}}$ & 2.07 & $<0.05$ & $<0.01$ \\
\hline Asparagine & 69.99 & 63.37 & 61.92 & 64.09 & 58.38 & 3.03 & 0.08 & 0.06 \\
\hline Cysteine & $71.91^{\mathrm{a}}$ & $68.98^{\mathrm{ab}}$ & $68.57^{\mathrm{ab}}$ & $65.91^{\mathrm{ab}}$ & $61.95^{\mathrm{b}}$ & 2.46 & $<0.05$ & $<0.05$ \\
\hline Glutamine & $75.52^{\mathrm{a}}$ & $71.00^{\mathrm{ab}}$ & $61.43^{\mathrm{bc}}$ & $65.24^{\mathrm{abc}}$ & $57.71^{\mathrm{c}}$ & 3.11 & $<0.01$ & $<0.01$ \\
\hline Glycine & $60.79^{a}$ & $54.54^{\mathrm{ab}}$ & $47.16^{\mathrm{b}}$ & $50.53^{\mathrm{ab}}$ & $48.20^{\mathrm{b}}$ & 3.43 & $<0.05$ & $<0.01$ \\
\hline Proline & $80.61^{\mathrm{a}}$ & $79.13^{\mathrm{a}}$ & $59.53^{\mathrm{b}}$ & $62.28^{\mathrm{b}}$ & $66.14^{\mathrm{b}}$ & 4.12 & $<0.01$ & $<0.01$ \\
\hline Serine & $92.01^{\mathrm{a}}$ & $90.26^{\mathrm{ab}}$ & $89.79^{\mathrm{ab}}$ & $90.01^{\mathrm{ab}}$ & $88.78^{\mathrm{b}}$ & 0.74 & $<0.05$ & $<0.05$ \\
\hline Tyrosine & 83.17 & 83.21 & 81.73 & 83.42 & 80.46 & 1.65 & 0.65 & 0.34 \\
\hline
\end{tabular}

Table 5. Apparent ileal digestibility of CP and amino acids of corn distillers dried grains with solubles (\%) $)^{1,2}$

CP, crude protein; DDGS, distillers dried grains with solubles; SEM, standard error of the mean; AA, amino acids.

${ }^{1}$ Sources of corn DDGS are described in Table $1 .{ }^{2}$ Values are means of 6 observations per treatment.

${ }^{3}$ Comparison between 5 DDGS. ${ }^{4}$ Comparison between full-oil DDGS and de-oiled DDGS.

${ }^{\mathrm{a}, \mathrm{b}, \mathrm{c}}$ Means in the same row with different superscripts are significantly different $(\mathrm{p}<0.05)$. 
Table 6. Standard ileal digestibility of CP and amino acids of corn distillers dried grains with solubles $(\%)^{1,2}$

\begin{tabular}{|c|c|c|c|c|c|c|c|c|}
\hline \multirow{2}{*}{ Items } & \multicolumn{2}{|c|}{ Full-oil DDGS } & \multicolumn{3}{|c|}{ De-oiled DDGS } & \multirow{2}{*}{ SEM } & \multicolumn{2}{|r|}{ p-value } \\
\hline & 1 & 2 & 3 & 4 & 5 & & DDGS $^{3}$ & Full-oil vs de-oiled $^{4}$ \\
\hline$\overline{\mathrm{CP}}$ & $78.79^{\mathrm{a}}$ & $75.14^{\mathrm{ab}}$ & $70.69^{\mathrm{ab}}$ & $72.97^{\mathrm{ab}}$ & $68.62^{\mathrm{b}}$ & 2.24 & $<0.05$ & $<0.01$ \\
\hline \multicolumn{9}{|l|}{ Essential AA } \\
\hline Arginine & 87.13 & 85.83 & 82.71 & 82.78 & 81.17 & 1.78 & 0.09 & $<0.01$ \\
\hline Histidine & $82.34^{\mathrm{a}}$ & $79.36^{\mathrm{ab}}$ & $75.16^{\mathrm{bc}}$ & $74.16^{\mathrm{bc}}$ & $70.73^{\mathrm{c}}$ & 2.10 & $<0.01$ & $<0.01$ \\
\hline Isoleucine & $83.33^{\mathrm{a}}$ & $80.78^{\mathrm{ab}}$ & $78.19^{\mathrm{ab}}$ & $79.38^{\mathrm{ab}}$ & $74.10^{\mathrm{b}}$ & 2.08 & $<0.05$ & $<0.05$ \\
\hline Leucine & $90.31^{\mathrm{a}}$ & $89.15^{\mathrm{a}}$ & $83.15^{\mathrm{b}}$ & $86.80^{\mathrm{ab}}$ & $82.57^{\mathrm{b}}$ & 1.47 & $<0.01$ & $<0.01$ \\
\hline Lysine & $71.15^{\mathrm{a}}$ & $64.55^{\mathrm{ab}}$ & $64.57^{\mathrm{ab}}$ & $63.47^{\mathrm{ab}}$ & $56.16^{\mathrm{b}}$ & 3.47 & $<0.05$ & $<0.05$ \\
\hline Methionine & $87.08^{\mathrm{a}}$ & $85.38^{\mathrm{a}}$ & $85.90^{\mathrm{a}}$ & $83.57^{\mathrm{ab}}$ & $80.01^{\mathrm{b}}$ & 1.45 & $<0.05$ & $<0.05$ \\
\hline Phenylalanine & 87.52 & 86.42 & 83.54 & 84.47 & 82.31 & 1.63 & 0.13 & $<0.05$ \\
\hline Threonine & 75.73 & 71.05 & 69.14 & 70.50 & 65.59 & 3.02 & 0.17 & 0.06 \\
\hline Tryptophan & 68.38 & 63.44 & 63.87 & 60.74 & 54.90 & 3.50 & 0.09 & 0.05 \\
\hline Valine & $81.50^{\mathrm{a}}$ & $78.62^{\mathrm{ab}}$ & $74.65^{\mathrm{ab}}$ & $77.65^{\mathrm{ab}}$ & $71.95^{\mathrm{b}}$ & 2.38 & $<0.05$ & $<0.05$ \\
\hline \multicolumn{9}{|l|}{ Nonessential AA } \\
\hline Alanine & $84.90^{\mathrm{a}}$ & $82.65^{\mathrm{ab}}$ & $77.13^{\mathrm{b}}$ & $78.80^{\mathrm{ab}}$ & $75.84^{\mathrm{b}}$ & 2.07 & $<0.05$ & $<0.01$ \\
\hline Asparagine & $75.49^{\mathrm{a}}$ & $69.26^{\mathrm{ab}}$ & $67.29^{\mathrm{ab}}$ & $69.08^{\mathrm{ab}}$ & $63.11^{\mathrm{b}}$ & 3.03 & $<0.05$ & $<0.05$ \\
\hline Cysteine & 81.06 & 78.33 & 77.74 & 75.09 & 71.74 & 2.46 & 0.08 & $<0.05$ \\
\hline Glutamine & $79.47^{\mathrm{a}}$ & $75.51^{\mathrm{ab}}$ & $65.62^{\mathrm{bc}}$ & $69.39^{\mathrm{abc}}$ & $61.87^{\mathrm{c}}$ & 3.11 & $<0.01$ & $<0.01$ \\
\hline Glycine & $79.69^{a}$ & $74.07^{\mathrm{ab}}$ & $67.61^{\mathrm{ab}}$ & $68.75^{\mathrm{ab}}$ & $65.61^{\mathrm{b}}$ & 3.43 & $<0.05$ & $<0.01$ \\
\hline Proline & $95.86^{\mathrm{a}}$ & $96.67^{\mathrm{a}}$ & $75.96^{\mathrm{b}}$ & $79.13^{\mathrm{b}}$ & $82.49^{\mathrm{b}}$ & 4.12 & $<0.01$ & $<0.01$ \\
\hline Serine & $94.03^{\mathrm{a}}$ & $92.50^{\mathrm{ab}}$ & $91.82^{\mathrm{ab}}$ & $92.03^{\mathrm{ab}}$ & $90.71^{\mathrm{b}}$ & 0.74 & $<0.05$ & $<0.05$ \\
\hline Tyrosine & 87.89 & 88.20 & 86.18 & 88.02 & 84.89 & 1.65 & 0.52 & 0.23 \\
\hline
\end{tabular}

CP, crude protein; DDGS, distillers dried grains with solubles; SEM, standard error of the mean; AA, amino acids.

${ }^{1}$ Sources of corn DDGS are described in Table $1 .{ }^{2}$ Values are means of 6 observations per treatment.

${ }^{3}$ Comparison between 5 DDGS. ${ }^{4}$ Comparison between full-oil DDGS and de-oiled DDGS.

${ }^{a, b, c}$ Means in the same row with different superscripts are significantly different $(p<0.05)$.

were no differences among the AID of 5 DDGS in Arg, Phe, Thr, Trp, Val, Asp, and Tyr. For AID of most AA, DDGS source 1 was the greatest and source 5 was the lowest; sources 2, 3, and 4 showed intermediate values relative to sources 1 and 5 . There were no differences for most AA among the two full-oil DDGS sources and separately among the three de-oiled DDGS sources, but there were significant differences in AID CP and AA $(p<0.05)$ between full-oil (sources 1 and 2) and de-oiled DDGS (sources 3, 4, and 5) except threonine, asparagine, and tyrosine.

The trend of SID for CP and AA was similar to AID. Among all of the essential AA analyzed, lysine and tryptophan had the lowest digestibility value. The SID for CP was $78.79 \%$ in DDGS source 1 (Table 6), this value was greater $(\mathrm{p}<0.05)$ than the value obtained for source 5 $(68.62 \%)$ but no different from sources 2,3 , and $4(75.14 \%$, $70.69 \%$, and $72.97 \%$, respectively). There were no differences among the SID of 5 DDGS in Arg, Phe, Thr, Trp, Cys, and Tyr. For the SID of most AA, DDGS sources 1 and 5 had the greatest and lowest values, respectively, and sources 2, 3, and 4 were intermediate in respect to them. For the SID values of most AA, there were no differences between DDGS sources 1 and 2, and no differences among sources 3, 4, and 5. However, there were significant differences $(\mathrm{p}<0.05)$ between the full-oil DDGS (sources 1 and 2) and de-oiled DDGS (sources 3, 4, and 5).

\section{DISCUSSION}

\section{Composition of distillers dried grains with solubles samples}

The concentrations of $\mathrm{CP}, \mathrm{EE}, \mathrm{NDF}, \mathrm{ADF}, \mathrm{P}$, ash, Lys, and the other AA in the DDGS used in this experiment were very similar or within the range of the previously published values (Cromwell et al., 1993; Pedersen et al., 2007; Stein et al., 2009a; Almeida et al., 2011; Anderson et al., 2012; NRC, 2012).

As expected, the concentration of EE in full-oil DDGS $(8.66 \%$ to $10.40 \%)$ was greater than the de-oiled DDGS ( $2.50 \%$ to $3.22 \%)$. The relative low oil content of de-oiled DDGS were similar to the $2.7 \%$ fat content (DM basis) reported by Saunders and Rosentrater (2009). As the oil was removed in de-oiled DDGS, GE was decreased and concentrations of $\mathrm{CP}$ and fiber were increased slightly or proportionately (Jacela et al., 2011).

In this study, as the CDS ratio increased, the color of DDGS sources 2, 4, and 5 were darker ( $\mathrm{L}^{*}$ decreased) than sources 1 and 3 , respectively. It was not expected that 
DDGS source 5 was a little darker than source 4 although its CDS ratio was lower than source 4 , and the reason may be that the processing, fermentation and drying equipment of source 5 were different with that of sources 3 and 4 , and caused more heat damage (Maillard reactions). The fiber content in sources 2,4 , and 5 were lower than in sources 1 and 3. The above results agree with several published studies that DDGS would become lighter in color, and AA increased while fat decreased as the CDS content added to WDG reduced; the reason being that CDS contain more fat and total soluble sugars but less fiber than WDG (Kingsly and Ileleji, 2009; Kingsly et al., 2010; Probst et al., 2013). CDS contains more minerals than WDG (Jacela et al., 2011), therefore the concentrations of $\mathrm{P}$ and ash in sources 2, 4, and 5 were greater than sources 1 and 3 , respectively.

In this experiment, there were two "unusual" findings in de-oiled DDGS compared with the previous results in traditional full-oil DDGS. The processing and equipment between DDGS source 3 and 4 were similar to each other but different from source 5, so comparisons just focus on source 3 and 4. Firstly, DDGS source 4 was not greater and even had a less fat than source 3 as the CDS ratio increased, which does not agree with the published reports that more CDS resulted in a greater fat concentration in DDGS (Ganesan et al., 2008; Kingsly et al., 2010). The other finding was that the AA concentrations in DDGS sources 3 and 4 were nearly equal, which was not in agreement with previous results for full-oil DDGS where the AA and CP concentration would decrease as the CDS increased (Ganesan et al., 2008; Kingsly et al., 2010). To our knowledge, this is the first report of the comparison of composition in de-oiled DDGS with different CDS ratios. The reason of the unusual findings we suspect is the removal of oil makes it much less concentrated in CDS than that of no oil extracted process, which then makes the AA increase slightly in CDS of de-oiled DDGS.

\section{Ileal amino acid digestibility}

The average AID and SID of $\mathrm{CP}$ and AA for the 5 DDGS in this study are close to the values in NRC (2012). However, there was only one average value for the three kinds of corn DDGS (based on their oil level) in NRC (2012), which indicated that no trusted data for middle oil and low oil DDGS had been reported before the NRC (2012) published. In our study, the AID and SID of CP and most of AA in full-oil DDGS are greater than the NRC (2012), but for that of de-oiled DDGS, they were similar or less than the NRC (2012) values.

Similar to Stein et al. (2009a), of all the AA analyzed, the SID of lysine (from $56.16 \%$ to $71.15 \%$ ) and tryptophan (from $54.90 \%$ to $68.38 \%$ ) had the lowest values and largest variation, which suggests reduced availability of these two AA and the different levels of Maillard reactions in the five
DDGS. The order of SID Lys from large to small in 5 DDGS sources trended according with the color $\left(\mathrm{L}^{*}, \mathrm{a}^{*}\right.$, and $b^{*}$ ) values within full-oil DDGS (source 1 vs 2 ) and deoiled DDGS (source 3 vs 4 or source 3 vs 5), respectively, but was not applicable for all the DDGS. This result indicated that DDGS color could be correlated with nutritional components, CDS ratio and AA digestibility of DDGS if the DDGS came from the same plant or plants had similar processing (Ganesan et al., 2008; Kingsly et al., 2010). However, color cannot accurately predict digestible lysine and other AA contents among DDGS sources which come from different processing (Urriola et al., 2013).

There were many reports on AA digestibility of full-oil (traditional) corn DDGS in pigs, and the values of sources 1 and 2 in our study had similar or in the range of previously reported values (Fastinger and Mahan, 2006; Almeida et al., 2011). However, for the de-oiled DDGS, very limited data can be referenced (Jacela et al., 2011; Ren et al., 2011).

Although there only 5 DDGS samples, considerable variation could be found in their AA digestibility. For the mean AID and SID of CP and most (more than 10) of AA, the sequence from greatest to lowest is DDGS source $1>$ source $2>$ source $4>$ source $3>$ source 5 . There were no or almost no significant difference within the full-oil DDGS (source 1 and 2) and de-oiled DDGS (source 3, 4, and 5) in AA digestibility, respectively. But the AID and SID CP and most of AA in full-oil DDGS (source 1 and 2) were greater $(p<0.05)$ than the de-oiled DDGS (source 3, 4, and 5). The AA concentrations in the 5 DDGS were very similar, so there are three possible reasons to explain the difference for SID of AA between full-oil DDGS and de-oiled DDGS. One is the difference of processing. To be compared with full-oil DDGS production, de-oil DDGS had undergone the oil extraction procedure and were exposed to more heat damage and Maillard reactions. The second reason may be due to the greater fiber content in de-oiled DDGS, as often reported, de-oiled DDGS have a higher fiber content, and high fiber such as NDF may reduce AA absorption and increase endogenous nitrogen and AA excretion, consequently decreasing the AA digestibility (Schulze et al., 1995; Lenis et al., 1996). The third possible reason is the inclusion of additional fat in the diet may delay gastric emptying, which could increase the AID of AA in growing pigs (Li and Sauer, 1994; Kil et al., 2011).

The AID and SID of CP and most AA for DDGS source 1 were greater than source 2 as the CDS ratio increased. These results are in agreement with previous research. The theory is that an increase CDS would increase total soluble sugars (reducing sugars) content (Kingsly et al., 2010) and the dryer temperature could lead to more Maillard reactions and lower AA digestibility (Martinez-Amezcua et al., 2007; Pahm et al., 2008; Stein et al., 2009a; Soares et al., 2012). But this theory maybe not be suitable for the de-oiled 
DDGS as indicated by the results of the present study. It is not clear why most SID AA increased as the CDS ratio increased in de-oiled DDGS (source 3 vs 4). We speculate that the reason also may lie in the oil extraction process. Because the oil extraction procedure removes the oil in the corn germ that then undergoes steaming and roasting $\left(98 \pm 2^{\circ} \mathrm{C}\right)$, pre-pressing $\left(95 \pm 2^{\circ} \mathrm{C}\right)$, desolventizing $\left(110^{\circ} \mathrm{C}\right)$ etc., which leads to more heat damage in de-oiled corn protein and germ meal than that of full-oil DDGS, therefore, WDG may cause lower AA digestibility in de-oiled DDGS and could relatively reduce the negative effect of CDS on AA digestibility.

As for the DDGS source 5, it had a middle CDS ratio compared with sources 3 and 4, but the AID and SID CP and AA were the lowest in the three de-oiled DDGS. From the analyzed composition of sources 3, 4, and 5, we find that source 5 had the lowest EE concentration and L*, which indicated it had the highest oil extract efficiency and the most heat damage (Fastinger and Mahan, 2006). We suspect the reason for the lowest SID AA in source 5 was the processing and equipment used to produce source 5 which were different from sources 3 and 4, especially for the drying procedure. Source 5 was dried by both tube bundle dryer (about $1 / 2$, using superheated steam, $285^{\circ} \mathrm{C}$ ) and cage mill flash dryer (about $1 / 2$, using saturated steam, $180^{\circ} \mathrm{C}$ to $200^{\circ} \mathrm{C}$ ) to drying the WDG and CDS to DDGS, and then mixed together, while sources 3 and 4 were dried only by tube bundle dryer.

In conclusion, full-oil corn DDGS in this study had greater SID of CP and AA than de-oiled DDGS; higher CDS ratios tended to decrease the SID AA in full-oil DDGS but not in de-oiled DDGS; and compared to CDS ratio, processing, especially drying, may have a greater effect on AA digestibility of DDGS.

\section{ACKNOWLEDGMENTS}

This research was financially supported by the National Natural Science Foundation of China (31372316) and Special Public Sector Fund in Agriculture (200903006).

\section{REFERENCES}

Almeida, F. N., G. I. Petersen, and H. H. Stein. 2011. Digestibility of amino acids in corn, corn coproducts, and bakery meal fed to growing pigs. J. Anim. Sci. 89:4109-4115.

Anderson, P. V., B. J. Kerr, T. E. Weber, C. J. Ziemer, and G. C. Shurson. 2012. Determination and prediction of digestible and metabolizable energy from chemical analysis of corn coproducts fed to finishing pigs. J. Anim. Sci. 90:1242-1254.

AOAC International (AOAC). 2007. Official Methods of Analysis. 18th ed. W. Hortwitz and G. W. Latimer Jr., editors. AOAC Int., Gaithersburg, MD, USA.

Cromwell, G. L., K. L. Herkelman, and T. S. Stahly. 1993.
Physical, chemical, and nutritional characteristics of distillers dried grains with solubles for chicks and pigs. J. Anim. Sci. 71:679-686.

Fastinger, N. D. and D. C. Mahan. 2006. Determination of the ileal amino acid and energy digestibilities of corn distillers dried grains with solubles using grower-finisher pigs. J. Anim. Sci. 84:1722-1728.

Ganesan, V., K. Muthukumarappan, and K. A. Rosentrater. 2008. Effect of moisture content and soluble level on the physical, chemical, and flow properties of distillers dried grains with solubles (DDGS). Cereal Chem. 85:464-470.

Jacela, J. Y., J. M. DeRouchey, S. S. Dritz, M. D. Tokach, R. D. Goodband, J. L. Nelssen, R. C. Sulabo, R. C. Thaler, L. Brandts, D. E. Little, and K. J. Prusa. 2011. Amino acid digestibility and energy content of deoiled (solvent-extracted) corn distillers dried grains with solubles for swine and effects on growth performance and carcass characteristics. J. Anim. Sci. 89:1817-1829.

Kil, D. Y. and H. H. Stein. 2011. Dietary soybean oil and choice white grease improve apparent ileal digestibility of amino acids in swine diets containing corn, soybean meal, and distillers dried grains with solubles. Rev. Colomb. Cienc. Pecu. 24:248-253.

Kingsly, A. R. P., K. E. Ileleji, C. L. Clementson, A. Garcia, D. E. Maier, R. L. Stroshine, and S. Radcliff. 2010. The effect of process variables during drying on the physical and chemical characteristics of corn dried distillers grains with solubles (DDGS) - Plant scale experiments. Bioresour. Technol. 101:193-199.

Kingsly, A. R. P. and K. E. Ileleji. 2009. Sorption isotherm of corn distillers dried grains with solubles (DDGS) and its prediction using chemical composition. Food Chem. 116:939-946.

Lenis, N. P., P. Bikker, J. van der Meulen, J. T. van Diepen, J. G. Bakker, and A. W. Jongbloed. 1996. Effect of dietary neutral detergent fiber on ileal digestibility and portal flux of nitrogen and amino acids and on nitrogen utilization in growing pigs. J. Anim. Sci. 74:2687-2699.

Li, S. and W. C. Sauer. 1994. The effect of dietary fat content on amino acid digestibility in young pigs. J. Anim. Sci. 72:17371743.

Liu, K. 2011. Chemical composition of distillers grains, a review. J. Agric. Food. Chem. 59:1508-1526.

Martinez-Amezcua, C., C. M. Parsons, V. Singh, R. Srinivasan, and G. S. Murthy. 2007. Nutritional characteristics of corn distillers dried grains with solubles as affected by the amounts of grains versus solubles and different processing techniques. Poult. Sci. 86:2624-2630.

NRC. 1998. Nutrient Requirements of Swine. 10th rev. ed. Natl. Acad. Press, Washington, DC, USA.

NRC. 2012. Nutrient Requirements of Swine. 11th rev. ed. Natl. Acad. Press, Washington, DC, USA.

Pahm, A. A., C. Pedersen, D. Hoehler, and H. H. Stein. 2008. Factors affecting the variability in ileal amino acid digestibility in corn distillers dried grains with solubles fed to growing pigs. J. Anim. Sci. 86:2180-2189.

Pedersen, C., M. G. Boersma, and H. H. Stein. 2007. Digestibility of energy and phosphorus in ten samples of distillers dried grains with solubles fed to growing pigs. J. Anim. Sci. 85:1168-1176. 
Probst, K. V., K. E. Ileleji, R. P. K. Ambrose, C. L. Clementson, A. A. Garcia, and C. A. Ogden. 2013. The effect of condensed distillers solubles on the physical and chemical properties of maize distillers dried grains with solubles (DDGS) using bench scale experiments. Biosyst. Eng. 115:221-229.

Ren, P., Z. Zhu, B. Dong, J. Zang, and L. Gong. 2011. Determination of energy and amino acid digestibility in growing pigs fed corn distillers' dried grains with solubles containing different lipid levels. Arch. Anim. Nutr. 65:303-319.

Saunders, J. A. and K. A. Rosentrater. 2009. Properties of solvent extracted low-oil corn distillers dried grains with solubles. Biomass Bioenergy 33:1486-1490.

Schulze, H., P. van Leeuwen, M. W. Verstegen, and J. W. van den Berg. 1995. Dietary level and source of neutral detergent fiber and ileal endogenous nitrogen flow in pigs. J. Anim. Sci. 73:441-448

Soares, J. A., H. H. Stein, V. Singh, G. S. Shurson, and J. E. Pettigrew. 2012. Amino acid digestibility of corn distillers dried grains with solubles, liquid condensed solubles, pulse dried thin stillage, and syrup balls fed to growing pigs. J. Anim. Sci. 90:1255-1261.

Stein, H. H., S. P. Connot, and C. Pedersen. 2009a. Energy and nutrient digestibility in four sources of distillers dried grains with soluble produced from corn grown within a narrow geographical area and fed to growing pigs. Asian Australas. J. Anim. Sci. 22:1016-1025.
Stein, H. H., B. Sève, M. F. Fuller, P. J. Moughan, and C. F. M. de Lange. 2007. Invited review: Amino acid bioavailability and digestibility in pig feed ingredients: Terminology and application. J. Anim. Sci. 85:172-180.

Stein, H. H., C. F. Shipley, and R. A. Easter. 1998. Technical note: a technique for inserting a T-cannula into the distal ileum of pregnant sows. J. Anim. Sci. 76:1433-1436.

Stein, H. H., M. L. Gibson, C. Pedersen, and M. G. Boersma. 2006. Amino acid and energy digestibility in ten samples of distillers dried grain with solubles fed to growing pigs. J. Anim. Sci. 84:853-860.

Stein, H. H. and G. C. Shurson. 2009b. Board-Invited review: The use and application of distillers dried grains with solubles in swine diets. J. Anim. Sci. 87:1292-1303.

Urriola, P. E., L. J. Johnston, H. H. Stein, and G. C. Shurson. 2013. Prediction of the concentration of standardized ileal digestible amino acids in distillers dried grains with solubles. J. Anim. Sci. 91:4389-4396.

Van Soest, P. J., J. B. Robertson, and B. A. Lewis. 1991. Methods for dietary fiber, neutral detergent fiber, and nonstarch polysaccharides in relation to animal nutrition. J. Dairy Sci. 74:3583-3597.

Williams, C. H., D. J. David, and O. Iismaa. 1962. The determination of chromic oxide in faeces samples by atomic absorption spectrophotometry. J. Agric. Sci. 59:381-385. 